\title{
Keynes, inflation and the public debt: How to Pay for the War as a policy prescription for financial repression?
}

\author{
SEBASTIAN TEUPE \\ University of Bayreuth
}

\begin{abstract}
Recent contributions on 'financial repression' and 'money illusion' have referred to Maynard Keynes's How to Pay for the War as a supporting document. This article discusses whether Keynes prescribed policies of 'financial repression' that were implemented in the United Kingdom, and other countries, following World War II. It seems reasonable that Keynes's writings were instrumental in translating British monetary experiences of the I920s and I930s into expectations of policymakers during and after World War II, including a belief in 'money illusion' that suggested the use of inflation for driving down real interest rates of public bonds. If this was the case, How to Pay for the War could indeed provide an important explanation for the why and when of 'financial repression'. This article argues that How to Pay for the War only partly provided support for a policy of 'financial repression', and none for using inflation as a 'tax gatherer' to the detriment of domestic savers in general. Crediting Keynes as a source for widespread 'money illusion' is also out of line with the historical record.
\end{abstract}

Keywords: public debt, Keynes, inflation, financial repression, war economy

JEL classification: $\mathrm{B}_{2} \mathrm{O}, \mathrm{E}_{3} \mathrm{I}, \mathrm{H}_{6}, \mathrm{~N}_{24}, \mathrm{~N}_{44}$

In the wake of increasing public debt levels, the literature on 'financial repression' has experienced a comeback. As a combination of artificially set interest ceilings, capital controls and inflation, 'financial repression' describes a set of policy tools that works in favour of public finances but is detrimental to domestic savers and bondholders (Roubini and Sala-i-Martin I995). The timing and economic effects of 'financial repression' have been demonstrated in detail (Battilossi 2005; Reinhart

Sebastian Teupe, Department of History, University of Bayreuth, Universitätsstr. 30, 95447 Bayreuth, Germany; email: sebastian.teupe@uni-bayreuth.de. I am grateful to the two anonymous referees and editor Stefano Battilossi for their substantial and helpful comments. I would also like to thank Stefanie Middendorf, Laura Rischbieter and the members of the DFG Research Network 'Doing Debt. Praxeology of Sovereign Debt in the Long 2oth Century' as well as Sebastian Knake for their comments on the draft, and Timur Öztürk for his feedback and valuable assistance. Financial support from the DFG Priority Programme 'Experience and Expectation: Historical Foundations of Economic Behaviour' (SPP I 859) is gratefully acknowledged. 
2OI2). Less attention has been paid to explaining its historical origins. There remains a puzzle as to why public officials pursued policies of 'financial repression' when they did. In the case of the United Kingdom (UK), high public debt levels had posed a problem in the wake of World War I. However, policies of 'financial repression' were not pursued until after World War II.

Today, Maynard Keynes's How to Pay for the War, published in I940, figures prominently in explanations of 'financial repression' (Keynes I940a). Written during the early stages of World War II, the pamphlet seems to have foreshadowed and legitimised the expropriation of savers' and bondholders' assets by the state. 'Financial repression' greatly helped to reduce the burden of debt after World War II; a burden that had persisted since World War I (Crafts 20I6). Why was the state successful after World War II when it had failed before? According to the economic literature, How to Pay for the War guided policymakers on two fronts. First, as Reinhart and Sbrancia (2015) claim, it illuminated the functioning of an 'inflation tax' by discussing the relations between state budgets and monetary depreciation. Second, as Akerlof and Shiller (20 IO) argue, How to Pay for the War fortified the academic claim for a widespread belief in 'money illusion'. The rising public deficits after 2007 have highlighted the contingency and importance of government debt-management policies (Turner 20 I I; Goodhart 20I0). Recently, How to Pay for the War has been explicitly proposed as guidance for financial policy in the face of increasing debt levels (Sanz Bas 2019).

Although inflation is not included in all definitions of 'financial repression', it has been generally considered instrumental in driving down real interest rates, as the devaluation of money devalued the nominal debt held by bondholders. For this to happen, however, the public needed to be unaware of the inflationary effects on bond yields. If investors had expected inflation, theory suggests, they would have protected themselves against the losses by indexing bonds, or withdrawing from the market altogether (Dornbusch and Draghi I990). The failure to take these actions is considered by Akerlof and Shiller (20IO) as proof of the existence of 'money illusion', and How to Pay for the War is one of their central reference points for making this claim. ${ }^{1}$ In addition, Keynes has been widely acknowledged as 'influential' in the management of public debt (Allen 2019, p. 44) and, by the time of World War II, 'could not simply be ignored' (Daunton 2002, p. I 77). Therefore, it seems plausible that Keynes's writings were instrumental in translating British monetary experiences of the I920s and I930s into strategies of policymakers during and after World War II when 'financial repression' was introduced.

This article tests the historical validity of such claims in light of the historical record, and by doing so addresses the question of the prerequisites of 'financial repression' in

1 'Money illusion' is usually not discussed as a prerequisite for 'financial repression' because of its doubtful validity as a concept in economics (Chytilova 20I7). Yet a widespread unawareness of monetary depreciation would have greatly facilitated public borrowing at negative real interest rates, and the sluggishness of inflation expectations in practice has been generally accepted (Bassetto and Galli 20I9). 
the I940s and I950s more generally. Taking Keynes's How to Pay for the War and the debate surrounding it as a starting point, this article investigates contemporary understandings of monetary values and their role in controlling public debt levels. Keynes's thoughts are positioned in the institutional setting of financial policy during and after World War II (Weir I989) in order to see whether the assumption of Keynesian influence on the management of public debt and 'financial repression' holds true. Indeed, the control of interest rates and the instrumentalisation of inflation by the state figure prominently in How to Pay for the War. A closer examination reveals, however, that the pamphlet only partly provided support for a policy of 'financial repression', and none for using inflation as a 'tax gatherer' to the detriment of domestic savers. Crediting Keynes as a source for widespread 'money illusion' is also out of line with the historical record. Finally, the evidence suggests that the label of an 'era of financial repression' is misleading. The low real interest rates that Keynes argued for were a direct outcome of learning from experience about postwar worlds and the burden of public debt. There is little to no evidence from this period that Keynes, the Treasury, or the Bank of England had an interest in using inflation as a 'mighty tax gatherer' over an extended period.

This article proceeds as follows: the first part situates How to Pay for the War in the long-term context of British debt management and its interpretation in the economic history literature. The second part analyses Keynes's How to Pay for the War and the supplementary publications that appeared before and after the pamphlet. This part begins with a short description of the contents, then focuses on what Keynes thought about inflation awareness in general, as well as the pamphlet's role in the management of public debt in particular. The third part provides an outlook on Keynes's role in public finances and inflation during and after World War II. The final part is the conclusion.

The development of British sovereign debt in the first half of the twentieth century has a stepped appearance. Starting from a negligible ratio of debt-to-Gross Domestic Product (GDP) in the early twentieth century, the debt rises steeply during World War I. This high level stabilises during the I920s and declines somewhat in the I930s before making another upward swing during World War II. In the second half of the twentieth century, the development of British sovereign debt resembles a slide. Shortly after World War II, the ratio drops steeply and continuously until well into the I990s. The two world wars had the same effect on public finances, but their aftermaths were astonishingly different. How did governments and the Treasury succeed after World War II at what they had failed to achieve two decades earlier?

From a superficial perspective, the answer seems easy. In both world wars, longterm domestic borrowing was 'the most significant factor' (Balderston I989; Broadberry and Howlett 2016, p. 204; End et al. 2019). However, after World War 
I, real interest rates on long-term bonds were high, mostly due to the deflationary policies of the time. This situation put downward pressure on prices and wages, lowering tax incomes and jeopardising the ability of the state to reduce public debt. In the late I920s, real Consol yields (i.e. the yields of a perpetual bond for which the government had - at least in principle - the option of redemption (Wormell 2002)), were 3 per cent higher than before World War I (Foreman-Peck 2002, p. I06). The modern theory of fiscal dominance suggests the possibility that - similar to the literature on 'financial repression' - in such a situation, monetary authorities may be unable to control inflation because the rate of economic growth lags behind the interest rate for bonds (Sargent and Wallace I98I; Blommestein and Turner 20I2; Allen 20I4; Sanusi and Akinlo 20I6).

In countries such as Germany or France after World War I, this theory had indeed been the case. Due to high inflation rates, the French and Germans had been able to clear their internal indebtedness by 'cheating' the debt holders (Foreman-Peck 2002, p. I I 5). In contrast, British officials tried to reintroduce gold convertibility and bring the pound back to its old parity with the US dollar (Moggridge I972; Allen 2012). To do this, a deflationary policy with a high discount rate was necessary to attract capital from abroad (Chwieroth 20I0). The effect was that, throughout the I920s, bondholders in the UK succeeded in receiving high yields despite widespread unemployment and antagonism towards the 'rentier' (Howson 1975; Maier I984; Daunton I996; McKibbin 20I0). There was a widely held belief 'that owners of government bonds should not profit from WWI and that future generations should not have to pay for WWI' (Nason and Vahey 2007, p. 290). Nevertheless, even continuous primary budget surpluses proved unable to reduce the debt significantly because of the high interest payments on consolidated government liabilities (Middleton 20 Io, p. 426).

Following World War II, the situation changed. Real interest rates turned negative due to inflation in a context of blocked investment alternatives and interest ceilings. Since there seems to have been a conscious decision to expropriate rentiers - as Keynes labelled the holders of government debt (McKibbin 20I3, p. 8I) - the term 'financial repression' was introduced to label and analyse the fiscal and monetary policies of industrialised countries in the decades following World War II, including the case of the UK (Battilossi 2005; Monnet et al. 20I4; Reinhart and Sbrancia 20 I 5; van Riet 20I8; Marinkov 2019). Originating in the early I970s, the term was first introduced by McKinnon (I973) and Edward S. Shaw (I973) to warn against financial strategies of developing countries that did not follow liberal ideals. Both authors established a close link between inflation and 'financial depression', but Shaw - who also elaborated on the problem of 'money illusion' - regarded the combination of interest ceilings and inflation as one of the most common strategies for achieving low real interest rates (Shaw I973, pp. 92-II2). The concept of 'financial repression' has now turned into a category of historical analysis, but it still carries implications for future policy decisions. 'Financial repression' can be defined as involving 'directed lending to the government by captive domestic audiences (such as pension funds 
or domestic banks), explicit or implicit caps on interest rates, regulation of cross-border capital movements, and (generally) a tighter connection between government and banks' (Reinhart 2012, p. 38). As a means for reducing debt-to-GDP ratios, 'financial repression' was usually accompanied by 'an equally steady dosage of inflation' (Roubini and Sala-i-Martin I995; Reinhart 2012, p. 39). Since such policies were widespread between the I940s and I970s, the entire period has been considered an 'era of financial repression' (Reinhart 20I2; Reinhart and Sbrancia 20 I 5).

In the case of Britain, Nick Crafts recently identified inflation as the driver of debt reduction after World War II (Crafts 20I6). By the late I950s, the ratio of national debt-to-GDP was lower than at the end of World War I, even though after the end of World War II the level of public debt had been almost twice as high (see Figure I). Against this background, Charles Maier's claim that there was a 'general understanding' after World War II to 'not burden the polity with the social and psychological toll of acute inflation' (Maier I984, p. I2 I) makes sense in comparison with German inflation after World War I, but not in light of Britain's own history when viewed through the lens of 'financial repression'. However, Maier's claim is well supported by the historical literature on British public finance after World War II. The management of debt, its institutional and organisational developments, the structure and level of indebtedness, the 'Treasury view' on state finances, the 'origins of cheap money', and the role of the Bank of England are all well documented (Sayers I956; Fforde I992; Howson I993; Wormell 2002; Allen 20I2, 20I9). If anything, inflation features as a 'threat' in those accounts, but not as a conscious policy choice (Howson I993, p. 2). How can this be explained?

Few have attempted to explain and understand the differences between the aftermaths of the two world wars in light of 'financial repression' and the specific relationship between sovereign debt management and monetary policy as suggested by the theory of fiscal dominance (Blommestein and Turner 20I2). Fforde (I992) focuses on Keynes's role mostly with respect to Anglo-American loan negotiations and does not discuss inflation as a policy prescription or 'tax gatherer'. Allen's study on the role of the Bank of England as a manager of public debt provides valuable insights into the decision-making process relevant for putting 'financial repression' into practice (Allen 20I9). However, neither this detailed study nor his insightful paper on government debt management and monetary policy in Britain since igig (Allen 20 I2) discusses the role of How to Pay for the War, nor raises the issue of public inflation awareness during the war.

Clearly, something changed between the I920s and the I950s regarding fiscal and monetary policy. However, much of economic history treats this development as a given, focusing on the economic effects of public debt levels rather than explaining how they came into existence. One can, of course, draw some inference from explanations based on the period of 'financial repression' alone. If authorities were willing and able to use inflation and interest ceilings as a means to reduce the public debt after World War II, they must have been either unwilling or unable to do so after World War I. Reinhart and Sbrancia (20 I 5 ) claim that, 'the role played by the combination of 


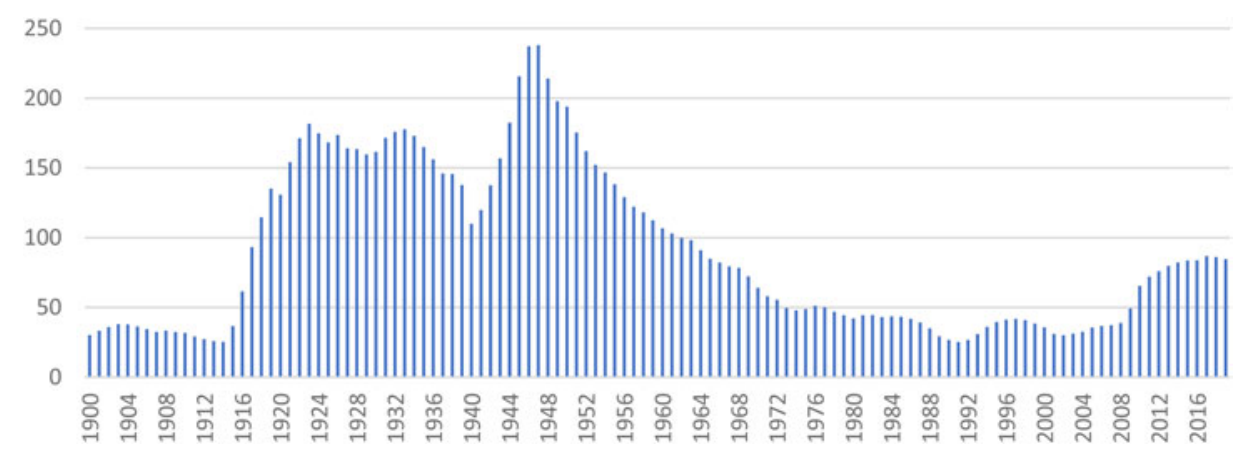

Figure I. Public net debt as total percentage of GDP, 1900-2019

Source: www.ukpublicspending.co.uk

some inflation and negative ex-post real interest rates in debt reduction was well understood ex-ante' by policymakers. As an example, they state that Maynard Keynes's How to Pay for the War is 'filled with discussion of inflation "as a mighty tax gatherer" (2015, p. 300). Reinhart and Sbrancia acknowledge that Keynes himself was sceptical about inflation, but they fail to mention that using inflation for taxation was not a novel insight at the time and was widely discussed by Keynes and inside the Treasury in the aftermath of World War I (Keynes I9I9, I923). John Stuart Mill had already argued in the I870s that governments had 'a direct interest in lowering the value of the currency, because it is the medium in which their own debts are computed' (Mill I 87I, p. 558; cited by Laidler I99I, p. 34).

By this criterion, the strategy could have been used after World War I. It is clear that, somehow, as Reinhart claims, the Great Depression and World War II were instrumental in changing government policies away from the idea of laissez-faire (Reinhart 20I2, p. 40). However, a more detailed historical account of How to Pay for the War might be able to identify more clearly where such ideas came from and whether inflation itself was actually considered a policy tool by Keynes. Did Keynes's writings - as implicitly claimed by the more recent literature on 'financial repression' - have the potential to change the preferences and expectations of policymakers in such directions?

The need for a historical explanation is informed by economic theory. High levels of debt pose a risk to credibility, and at a certain level - as Dornbusch and Draghi (I990, p. 6) state - creditors 'shy away' from bonds and ask for measures such as indexing. If this had happened after World War II in the UK - and other countries - debt reduction would hardly have been effective. Why indexing was seemingly not an option remains puzzling unless the institutional constraints are considered so powerful as to leave investors with no other choice. In Animal Spirits, however, the failure of indexing bonds is regarded as an indication of the failure to see through the "veil of inflation' (Akerlof and Shiller 20IO, p. 50), a failure that was supposedly pronounced and widespread at the height of 'financial repression' before the I960s. As evidence for 
ubiquitous 'money illusion', Akerlof and Shiller (2010) cite How to Pay for the War. The lack of financial literacy implied by 'money illusion' could provide an important prerequisite as to why 'financial repression' was deemed a successful strategy by policymakers and finance officers in favour of expropriating domestic savers, in particular the holders of public debt.

To what extent such views would have held true empirically (i.e. whether the public anticipated inflation) is difficult to answer. Economists and economic historians have been arguing for decades about the proper method for empirically estimating inflation expectations (Binder 20I6; Daniel and ter Steege 2020) and uncertainty (Cogley and Sargent 2015), and for theoretically understanding and modelling public expectations (Sargent 2013). The problem of 'money illusion' relates to this issue since it concerns the very fundamentals of making sense of any price data past, present or future. Institutions such as central banks play an important role, not only because they control inflation rates, but also because they can potentially reduce inflation uncertainty (Bredin and Fountas 20I8). However, the policy regime of central banks is not necessarily stable, and its independence is - especially in wars and financial crises - historically contingent (Allen 20I9).

A crucial point of contention in this debate is the extent to which historical experience influences inflation expectations beyond or even contrary to the information available to the public. As Malmendier and Nagel (20I6) argue, the public's inflation expectations might be informed by personal historical experience in the past as much as by economic models in the present. Given the importance of inflation expectations regarding the purchase of government bonds with fixed interest rates over long periods, there is reason to believe that such experience might have had an important influence. What complicates this situation, however, is that a majority of British people at the dawn of World War II had somewhat contradictory experiences with inflation and public bonds that are not comparable to the experience of Americans since the I950s.

Inflation during World War I caused food protests and calls for higher wages. In this sense, the public had been very much aware of rising prices, although they might not have seen the connection between aggregate demand and aggregate supply that stands at the centre of Keynes's analysis. Instead, the public blamed 'profiteers'. At a public meeting held in Harrington, Northamptonshire, to protest against increases in milk prices, the organiser told the crowd 'that the farmers were having the time of their lives, and were reaping a golden harvest at the expense of the country' (Coles I978, p. I60). This claim echoed public reactions since the early twentieth century in the US, when the 'high cost of living' was explained as being caused by the ignominious behaviour of individuals rather than monetary factors (Aldrich 2013). More recent historical research has suggested that, during World War I, food prices were a major concern for housewives across the UK, who became increasingly politicised by acting against these developments at a local level (Hunt 20IO).

However, following World War I, inflation was soon eliminated. Whoever had managed to hold on to government bonds experienced sizeable real returns during 
the I920s. The successful conversions of UK government bonds in the early I93os, during which the interest rate on wartime bonds was reduced from 5 to 3.5 per cent, signalled a limit to what the public was 'willing to endure', and it somewhat limited the burden on the Treasury. Nevertheless, at a time of a low or even negative rate of inflation (Crafts 20I6), the conversion had not significantly hurt the 'rentiers'. For Keynes, the management of public debt was a clear case of failure, especially since he held the view that high real interest rates usually worked to the detriment of the overall economy (Tily 2006).

The importance of Keynes advising the Treasury on permanently low interest rates for public debt during the war is widely documented and acknowledged (Howson I993; Aspromourgos 2014). However, Keynes's views on using inflation as a policy tool for managing public debt have received much less attention. While inflation was a consequence of war financing, and crucial for reducing the debt burden, its role for contemporary policy choices remains dubious. By the end of World War II, numerous countries across the world had become so highly indebted that public debt was considered a 'political problem of the first order' (Wallich I946, p. 293). Many contemporary commentators already suspected the return of inflationary forces. Authors such as Fry (I989) explicitly linked 'financial repression' to the Keynesian revolution, and inflationary expansion as a policy tool. More recently, however, Allen critically states that, "no reader of the archives can seriously believe that the Treasury or the Bank of England actually wanted to create unanticipated inflation' (Allen 20 I 4, p. 2 I2). Earlier historical accounts on financial policy and contemporary economic thinking have similarly argued that inflation was generally not 'expected to be a permanent problem' (Howson I993, p. 44). A closer inspection of How to Pay for the War and supplementary publications can provide important insights into the intellectual origins of 'financial repression' and the extent to which Keynes was instrumental in it.

In I939, Keynes was heavily engaged in a political campaign that his biographer Donald Moggridge calls 'the most sophisticated and successful of his many campaigns as a publicist' (Moggridge I992, p. 629). Keynes's aim was to solicit widespread support for a war-financing scheme as Britain was starting to mobilise. Keynes was realistic about the costs of mobilisation and its effects. He hoped to avoid rigid controls as much as inflation. At the centre of his plan was the idea of compulsory savings, or deferred payments. Stated simply, Keynes asked the working population to forego parts of its income gains in favour of state consumption. The idea was essentially a 'forced loan' - money that the British state was supposed to pay back once the war was over. Keynes spread his ideas via lectures, The Times, The Economic Journal, private and public discussions, radio and a pamphlet entitled How to Pay for the War, published in 1940. Although small in comparison with scholarly debates about his other works, Keynes's plan has elicited some historical research interest beyond its 
role for 'financial repression' (Trevithick 1975; Littleboy 1996; King 1998), most notably for its importance in the development of modern macro-economics and national accounting (Hicks I990; Kurabayashi I994; Tily 2009).

In devising and propagating his plan, Keynes's primary concern was the question of distribution, which he called the 'thorniest question of all' (Keynes I940a, p. 2). In contrast to normal times, Keynes explained, consumer goods in a war economy would not become more plentiful when production and working time were extended, because any additional output would have to be used for the war effort (I940a, p. 3). Thus, there were fewer consumption opportunities available to the public. At the same time, the increased demand for labour and longer working hours would put more money into the hands of the working people. Less certain was how the scarcity produced by the war economy would translate into the price system. If nothing was done, Keynes argued, a rise in prices was inevitable because of the disequilibrium between supply and demand. This situation would lead to much or all of the wage gains being sucked up by inflation. The money would then go to 'profiteers', the firms who sold the expensive products. Then, the money would go partly to the Treasury in the form of (excess profit) taxes and partly remain in the hands of profiteers, who would use it to buy public bonds. Keynes argued that this had happened in World War I. Inflation had proved to be 'much more cruel in equity terms than the most cruel of regressive taxes' (Maital I972, p. I 59).

Keynes had been preoccupied with the issue of prices and inflation from the beginning of the war, considering it 'one of the most urgent and important matters for the Home Cabinet' (Keynes I939b, p. 4). Price controls could help prevent labour from making wage demands. Keynes was in favour of this approach. From the beginning, however, he was sceptical as to whether it was sufficient. In September 1939, Keynes called the idea of trying to keep prices at prewar levels 'fanciful and highly unrealistic' (Keynes I939c, p. 3 I). How to Pay for the War presented a comprehensive plan centering on the idea of 'deferred payments'. The pamphlet also included a strategy for dealing with the postwar UK economy, and the widespread expectation of a slump, similar to what had happened after World War I. It thus combined Keynes's theoretical insights of the I930s with his historical experience of the I920s. Generally speaking, all receivers of income were supposed to forego part of their wage gains in exchange for a claim on future resources, which could then be used to balance under-consumption. The contribution of workers during the war, when the economy was working at full capacity, was supposed to move on a progressive scale. Lower incomes were exempted. The final publication, in which Keynes reacted to comments about his proposals, includes a detailed plan on family allowances, which he continued to support during the war (Daunton 2002, p. I8I), and a call for a capital levy after the war to finance the workers' claims.

The deferred payments, which would be placed with a range of institutions, such as the Post Office Savings Bank, friendly societies or trade unions, were to be released in the first postwar slump when demand was behind supply (Keynes I940a, pp. 
44-50). The technicalities of repayment were essentially dictated by the state. The interest rate was set by Keynes at 2.5 per cent - the same rate he envisioned for public bonds, which stands in contrast to Daunton's claim that there was no interest on deferred payments (Daunton 2002, p. I83). In a letter to the editor of The Times, Keynes argues that, 'in principle these loans would be in exactly the same position as the rest of the short-dated debt which the war will leave behind it' (Keynes I939d, p. 82).

Keynes was one of the most influential economists of his time, and in the late I93os and I940s his reputation was at its height. However, he had never been alone in providing policy suggestions, nor gone unchallenged. As the war economy threatened to unsettle British finance, government advisers and officials, from the Treasury to the Bank of England, had also become concerned with the proper methods for managing the economy. For many of them, Keynes's proposals offered useful analysis and guidance, and Keynes was more than willing to share and discuss his thoughts on how to pay for the war. The encouraging feedback that Keynes received certainly meant some support in the tedious task of implementing his 'radical plan for the exchequer'. There was widespread, almost unanimous approval from economists, including his academic antagonists Friedrich Hayek and Lionel Robbins.

At the Bank of England, Keynes's policy proposal even seems to have ended his 'long estrangement' from Montagu Norman, who thought it was 'the only solution' (Keynes I94Od, p. I02). In a letter to Keynes dated 28 February, Norman professed that he knew 'of no other specific than yours'. Norman suggested meeting with Keynes and Henry Clay to discuss some of the details (Norman I940, p. I04). Keynes happily agreed (Keynes I940e); Clay seemed a perfect fit. As Chief Economic Adviser at the Bank of England, Clay had already produced proposals that foreshadowed many of the issues Keynes addresses in How to Pay for the War. According to the Bank's official war history, these proposals were 'likely to have reached the Treasury in one form or another' (Bank of England I956, p. 28).

Clay's discussion stressed 'the two dangers of an inflationary rise in prices' due to higher wages on the one hand and the 'impact of civilian spending in reduced output of consumer goods' (Bank of England I956, pp. 28-9). Rhetorically, Clay had asked whether the latter could not be forestalled by a rise in income tax and a heavy taxation of non-essentials. In further proposals, he had raised a number of additional possibilities, and had hinted at the possibility of a 'compulsion to invest savings in Government new issues' (Bank of England I956, p. 58) - at least for institutional savings - while propaganda 'should do the same for small personal savings' (Bank of England I956, p. 6I). In general, however, Clay seems to have preferred a tax reform to 'cream off the rise in wages and profits, and to channel money into the Treasury (Bank of England I956, p. 56).

Similar to Keynes's, Clay's proposals display a ready awareness of the need to address the problem of war inflation from the outset. Clay was also sceptical regarding the imposition of 'Government control', which would 'only result in a general standstill' (Bank of England I956, p. 57). It is hardly surprising then that Clay, at least according 
to a letter that Keynes wrote to the editor of The Times privately, had displayed 'enthusiastic agreement' when confronted with the plan (Keynes I940d, p. I02). Keynes also described Clay as one of those economists 'who are also, and primarily perhaps, administrators' (Keynes I940d, p. I02), revealing Keynes's keen interest in circulating his ideas to those who had a say in devising policy.

In contrast to such enthusiastic agreement, parts of labour were noncommittal or even hostile (Toye 1999), as was the National Savings Association, which feared a crowding-out effect. While part of the critique centred on the problem of voluntarism, another part addressed the problem of inflation. When Keynes presented his plan to union members, he received sceptical reactions; they suggested 'that the value of the deferred pay was likely to be eradicated by future inflation' (Toye I999, p. I7). Barbara Wootton, a lecturer in Economics at Cambridge and Research Officer of the Trade Union Congress, praised Keynes's proposal for a capital levy in a lengthy review, arguing that this might 'diminish the very real danger that if our deferred pay ever is paid up, this will be done by inflation' (Wootton I940, p. I49).

This reaction suggests considerable public concern regarding inflation, especially on the part of labour. Keynes suggested that there should be some sort of indexing, but he also admitted that, given historical experience, it would be "“extraordinarily difficult to get an assurance" from the Treasury on these lines' (Toye I999, p. I7). This scepticism proved valid. When the Treasury ultimately issued - albeit on a much lower scale - a bond similar to what Keynes had envisioned, its value was eradicated by postwar inflation (ibid.). It seems ironic, therefore, that given inflation is a running thread throughout his work, Keynes seemed unwilling to discuss it as a serious element of the plan for future repayments. He seemingly had no problem following the suggestion of Henry Clay and others to drop a section on indexing compulsory savings because 'it would divert discussion from his main proposal' (Moggridge I992, p. 629). The most obvious explanation for this act is that Keynes did not consider an extended postwar inflation to be preferable or likely.

Early in the war, Keynes admitted the advantage of a rising price level for public finances: 'The aspect of higher prices as an instrument of revenue is not to be overlooked. Direct taxation can scarcely do all that is wanted' (Keynes I939b, p. 6). Since there was always inflation as a reserve position, the financing of the war itself was not of primary interest to Keynes. The goods ordered by the supply departments would be 'financed anyway'. The importance of devising a coherent plan of war finance was social - 'to prevent the social evils of inflation now and later' (Moggridge I992, p. 643). In Keynes's view, however, inflation was less a conscious policy and more the result of laissez-faire. At different points, he described inflation as 'nature's remedy', and in a much-quoted passage he explains the problem of assigning responsibility for it as the main 'advantage':

No one has to take the responsibility for inflation, not even the Chancellor of the Exchequer. The adoption of my plan would require the approval of the Labour Party. But they will never be asked to approve inflation. It will just happen. It is nature's remedy, ebbing up like the tides, 
silently and imperceptibly and irresistibly ... It greatly benefits some important interests. It oils the wheels everywhere, and a regime of rising wages and profits spreads an illusion of prosperity. So if one is to bet on the field, inflation must always be the favourite. (Keynes I939e, p. 77)

The term 'nature's remedy' implies a lack of agency on the part of labour. 'The workingmen', Keynes claims, had 'no. . choice' (I939e, p. 76); inflation would 'defeat' them, just as in the last war, so that the real gains would be diminished without any possibility of resistance. Wage demands would simply drive a 'vicious spiral' that could lead to an 'unlimited inflation' (I939e, p. 76). The reason Keynes believed that inflation had not run out of control lay in temporality: 'Wage adjustments and the like take time . . It is these time-lags and other impediments which come to the rescue' (I940a, p. 66). In World War I, there had been a 'time-lag of almost exactly a year' (I940a, p. 72). It was this time-lag that, according to Keynes, had prevented 'disaster' in the UK, referring to the hyperinflation experiences of countries such as Germany and Austria and violent protests elsewhere.

Keynes openly criticised union leaders for their futile wage demands: 'Like the dog in the fable, they lose the substance in gaping at the shadow' (I940a, p. 6). It would be incorrect to ascribe the demands to individual folly. Keynes admits 'that the better organized sections might benefit at the expense of other consumers' (ibid.). He was sure that 'in their minds and hearts the leaders of the trade unions' were aware of this futility 'as well as anyone else' (ibid.). He even thought the demands 'legitimate' as long as no alternative plan was presented. Therefore, it is crucial to regard Keynes's views on wage demands in a social context. His proposal was an attempt to change the rules of the game. This proposal, of course, presented a blow to orthodox views of non-interference. When Keynes discussed his plan with Pethick-Lawrence of the Labour front bench, who vehemently defended voluntary saving, Keynes felt he 'was up against such a terrific degree of nineteenth-century laissez-faire, that the discussion was more of historical than of current interest' (Keynes I940b, p. 98).

Keynes credited union leaders with a ready awareness of the consequences of inflation. It is less clear to what extent this appraisal held generally. At the time of the publication of How to Pay for the War, Keynes claimed that inflation was 'not yet understood by everyone' and that even economists had 'only got clear about it . . in the last quarter of a century’ (Keynes I940a, p. 70). However, Keynes's understanding of inflation awareness was itself hardly consistent. In a letter to the Editor of the New Statesmen, not long after having published How to Pay for the War, Keynes claims that everyone has become 'index-number conscious' (Keynes I940b, pp. I20-I). John Hicks, who debated Keynes's ideas in How to Pay for the War both publicly and privately, had, early on, expressed his irritation of Keynes's readiness to think that - while highly problematic in terms of distributive justice - inflation would at least be able to solve the problem of war financing. Hicks could not see how organised labour would be content with a fall in the standard of living induced by inflation rates outstripping nominal wage gains: 'Surely you will agree that that must mainly defeat the aim of the price rise. It seems to me that it will defeat it more quickly than in the last war' (Hicks I939, p. 33). 
More than anything else, the seemingly contradictory statements reveal Keynes's insight into the constantly changing nature of inflation and public awareness. This insight had been evolving over the previous two or three decades. During World War I, Keynes had been in the Treasury, but despite considerable price increases, he claims he had 'never at that time heard our financial problem discussed along these lines' (Keynes I940a, p. 70). In his 'Tract on Monetary Reform', Keynes describes the public as 'generally . . . very slow to grasp the situation and embrace the remedy' (Keynes I923, p. 40) when governments attempted to tax away their wealth through inflation. Initially, the public might even hoard money in the belief that prices will soon come down again. By the early I920s, Keynes thought that there was a temporal limit to this hoarding of money. As soon as discovery set in, the public would begin to change their habits, either by turning to durable objects, by reducing the amount of money they kept, or by employing foreign money (Keynes I923, p. 4I). Keynes describes the continuous use of depreciated money by the public not so much as a problem of awareness but as a problem of convenience and a lack of alternatives:

Like other conveniences of life the use of money is taxable, and, although for various reasons this particular form of taxation is highly inexpedient, a government can get resources by a continuous practice of inflation, even when this is foreseen by the public generally, unless the sums they seek to raise in this way are very grossly excessive. (Keynes I923, p. 43)

In The Times articles of November I939, Keynes seems to follow Hicks's impression of an increased public awareness of inflation since World War I, and its institutional implications. Calling to mind the necessity of a time-lag between price increases and wage demands, Keynes argues that, 'there are today many wage rates linked by agreement with the cost of living, so that the two move together' (Keynes I939a, p. 43). Keynes also stresses the same problem of an increasing inflation awareness in a reply letter to a $\mathrm{Mr} \mathrm{H}$. Barrow. Mr Barrow, who himself favoured inflation, accused Keynes of being a deflationist. It is, Keynes states, 'perhaps, a comfort' that inflation is 'always there. . . to fall back on'. However, given the necessary time-lag, Keynes's doubts whether 'in modern conditions' this time-lag would be 'long enough to do the trick'. As everyone, according to Keynes's, had become 'index-number conscious', the result would be that wages would pursue prices 'with not so lame a foot'. Summing up his reply, Keynes states: 'And this new fact means that the old-type laissez-faire inflation is no longer to be relied upon' (Keynes I940c, pp. I20-I).

Working people had not been the only ones becoming more conscious. One year earlier, Keynes had expressed his hope for lower inflation rates due to a heightened awareness on the part of public officials as well: 'We have adopted price controls at the outset and are more conscious of the problem' (Keynes I939e, p. 78). While the problem consciousness that Keynes mentions here referred to the authorities in charge of economic policy, Keynes also assumed a deeper transformation of inflation awareness affecting the whole of society. Nevertheless, Keynes's assessment about the 
state of inflation awareness at that time remained necessarily speculative because it was understood to be an empirical fact based on historical experiences rather than a timeless quality of rational economic actors. Nowhere does Keynes imply, however, a prevalence of widespread 'money illusion' in times of inflation.

Given the preoccupation of How to Pay for the War with the distribution of debt rather than with inflation per se, it is puzzling that the latter has attracted much more attention in the scholarly literature. When considering the inflation of World War I, Keynes concludes: 'No one benefited except the profiteer. The seeds of much subsequent trouble were sown. And we ended up with a national debt vastly greater in terms of money than was necessary and very ill distributed through the community' (Keynes I940a, p. 73). The large debt payments required a high level of taxation to pay the 'rentiers'. Economic historians such as Foreman-Peck (2002, p. I08) have added that the high interest rates necessary to attract investors also crowded out private sector investments to the detriment of employment. The young Keynes had been rather unprepared for the possibility of financing a long war through inflation and massive borrowing. In I9I4, as a 3 I-year-old, Keynes argued that the war 'would be short since governments would find it hard to appropriate the resources needed to support the war' (Maital I972, p. I 58). How to Pay for the War was the result of having learned from historical experience and personal misjudgement.

By the early I920s, Keynes had developed a much more informed understanding of the relations between public debt, monetary policy and exchange rates. The level of internal debt figured as the crucial variable defining the scope of monetary policy, and thus the exchange rate. In a lecture to the Institute of Bankers, Keynes stated:

You can always restore the currency to any value you like if you want to provided that it does not increase the claims of the bond-holders beyond what is tolerable. If it does, the Government is certain to be forced to inflate again, and the work will be undone. (Keynes I922, p. 46)

This lecture was a typically Keynesian attack on the 'inactive bond-holding rentier class', a class that Keynes had never been able to define precisely (McKibbin 20I3). In this lecture, he uses rentiers as a 'class' whose earnings came from secure bonds rather than from some sort of entrepreneurial capital or physical work. Based on this distinction, Keynes offered a defence of the principle that contracts generally referred to nominal rather than real monetary values, which meant that, while the numbers remained fixed, their real value could fluctuate with the price level. Some of Keynes's contemporaries questioned the 'justice' of such contracts once the value of money deteriorated. Keynes was unwilling to accept this argument because he thought it was 'utterly impossible to compel the active part of the community to hand over an undue proportion to the bondholding class' (Keynes I922, p. 47). As McKibbin (20I3) argues, this view was a sociological rather than an economic analysis.

In his 'Tract on Monetary Reform', Keynes states that, 'it would be too cynical to suppose that, in order to secure the advantages (of money depreciation, ST), 
governments (except, possibly, the Russian government) depreciate their currencies on purpose' (Keynes I923, p. 53; also see White et al. 2009). However, if there were an intolerable level of debt, countries would either repudiate the debt, impose a capital levy, or inflate away the debt as Austria and Germany had done. Keynes's 'great objection' to the third option was that it fell on small savings just as much as on large ones while possibly enriching 'the ordinary entrepreneur capitalist'. At that time, he nevertheless expected inflation to be the preferred choice of dealing with high levels of debt - even though it was 'unjust, inequitable, disastrous' (Keynes I922, p. 49).

Keynes was, at that time, sympathetic towards a capital levy, which had widespread support among the working classes (Daunton I996), but he believed that the small savers would be too conservative to vote for it. When writing How to Pay for the War, Keynes was still sympathetic towards a capital levy in principle, as is evident by his willingness to include such a levy as a means to finance the workers' claims after the war. However, shortly before the end of the war, the National Debt Enquiry, of which Keynes, James Meade and Lionel Robbins were members, found that a 'capital levy did not provide a useful device to reduce the debt' (Daunton 2002, p. I 88). Therefore, English mainstream economists no longer seriously advocated this approach. The Labour Party, however, came to be embrace it soon after the war as an additional means to lower the debt, to achieve equality and, as Hicks argued, to suppress inflation ((Daunton 2002, p. 216).

Keynes's proposal in How to Pay for the War was driven by the unequal burden of national debt resulting from Word War I, which, contrary to his expectations, had not been inflated away. Instead, the British state had preferred deflation for reasons that Keynes, as McKibbin states, 'was never quite able to explain' (McKibbin 20I3, p. 83). It is unsurprising that, against this backdrop, Keynes's solution of deferred pay introduced a specific link to the management of the public debt. It was not that Keynes opposed borrowing by the state in favour of taxation; he thought that the idea, contrary to Clay, that war expenditures should be met 'out of increased current effort and diminished current consumption' via taxation to be neither 'just' nor 'wise'. Keynes compassionately wrote that it would make 'all the difference in the world to each individual personally whether the excess of his income over his consumption is taken from him by tax or by loan'. A loan would mean an addition to 'his wealth, to his security, and to his comfort in facing the future', something that taxation would not provide (Keynes i939a, p. 45).

It is true that Keynes himself was much more concerned with the problem of wage adjustment than with debt devaluation. In his exchange with Mr Barrow, who had called for inflation to lessen the debt burden, Keynes remains lofty in general terms and only touches briefly upon the specific issue of national debt. There is 'much sentiment of this kind underground', Keynes acknowledges, 'too shy to lift its head for execution ... And there is a flavour of naughtiness about it which some members of the Left find irresistible; there must be something good, they feel, in a proposal so repugnant to all respectable citizens.' However, while Keynes admits that 'the 
reduction in the burden of the National Debt is a subsequent result of reducing the value of money', he does not see much value in it as it made 'no significant contribution to the current financing of the war' (Keynes I940c, pp. I20-I). Thus, Keynes treated the proposal primarily as a danger to his non-inflationary scheme. His reply to Mr Barrow offers no clear hint as to whether Keynes might also have favoured an inflationary reduction of debt after the war, but it is unlikely.

One important indication of this view is that Keynes regarded his plan as rather a burden to the Treasury precisely because it tried to rule out inflation:

A system of deferment of pay - and equally, a system of highly successful voluntary savings will leave us with a larger national debt, measured in terms of real value, than if we adopt the method of imperfectly successful voluntary savings supplemented by inflation. For inflation is a mighty tax-gatherer. But the Treasury and the tax-payer of the future need only remain in doubt if they expect the price level reached by inflation to continue permanently. For the national debt under the inflationary system is likely to be larger in terms of money than under the system of compulsory savings; so that if prices subsequently fall back, the benefits of inflation will have proved illusory even to the Treasury. (Keynes I940a, pp. 68-9)

Thus, How to Pay for the War was less inflationary in terms of policy prescription than the War Finance Group, including economists such as Berry, Durbin, Gaitskell and Piercy, had advocated in its meetings. These economists, who took over administrative duties during the war, regarded inflation as having the advantage of reducing real debt, and they argued in favour of it. It should be noted, however, that Gaitskell and others always envisioned a 'moderate and controlled inflation' that was restricted to a wartime economy, and that they were themselves enthusiasts of Keynes's non-inflationary ideas (Howson I993, pp. 75-6). This view was also in line with Labour's postwar full employment policy, the 'central point' of which was 'the maintenance of aggregate demand to prevent both inflation and deflation' (Howson I993, p. 92). This highlights the contemporary view of regarding monetary fluctuations as largely resulting from private investment rather than monetary policy. Like Keynes, his economist colleagues were prepared to use controls against the immediate postwar inflation and seemed utterly unprepared for continuous inflation beyond the envisioned postwar slump.

\section{III}

After Keynes had published How to Pay for the War, he became frustrated. The general impression he received was that the public seemed not to take the financial problem of the war seriously. In terms of public financing, his ideas in How to Pay for the War were half-heartedly implemented at best (Toye I999), and deferred payments did not play a crucial role in generating financial resources (Sayers I956). From a policy perspective, the suggestions of economic administrators such as Clay (i.e. to rely on taxation) proved more influential (Daunton 2002). Thus, Keynes's proposals document a thoughtful analysis on inflation, war economies and the public debt, but they also reveal the boundaries of his influence. 
At the same time, however, the Treasury was confronted with the practical necessities of public financing. In this context of thinking about the possibilities of managing interest rates, Keynes played a more crucial role (Moggridge 2002, p. I I4). Sayers credits Keynes with being a decisive factor in the patient interest policy of the Treasury. Keynes and other economists were not only decisive in explaining the advantages of low interest rates - of which the officials were readily aware (Allen 2019, p. 30) - they were more generally important 'in their illumination of the fundamental causes of war inflation' (Sayers I956, p. 204).

Low interest rates became a predominant theme for financing the war, about which Keynes made a number of practical suggestions. The high interest rates that the Treasury had had to pay during Word War I had clearly been a trauma. Pointing out how much the Treasury could save simply by borrowing at half a percentage point less was one of Keynes's first publicity stunts shortly after the war began. His 'Sibylline books' principle put pressure on the public to invest in gilts, as each new issue would have a longer maturity and was, thus, considered less attractive (Allen 20I9, p. 48).

It seems safe to say that Keynes, despite his contempt for rentier incomes, did not envision an inflationary postwar era of 'financial repression'. Although he provided important advice for managing long-term interest rates, he never expected Treasury officials to be able to actually 'cheat' the public over longer periods of time through a steady dosage of inflation. Even more radical policy advisers, such as James Meade, adhered to the principle of low inflation. Disagreeing with Keynes about the 'proper rewards' of private savings, Meade stated:

The more I examine the problem, the more certain it seems to me that the proper radical solution is to get interest rates down to or towards zero, thereby killing two birds with one stone: avoiding economic stagnation and removing the burden of debt interest on the budget. The only argument against this would be if it led to inflation; but within reason such a development could be counteracted by running a budgetary surplus. (Cabinet Office Diary, p. 46; see Howson I993, p. 50)

The years following World War II did not witness a continuing fall in interest rates but, instead, fluctuations. Howson argues that Dalton's policy of lowering nominal interest rates was initially successful because of its unanticipated inflationary consequences, but this policy could not be sustained as expectations adapted (Howson I993, p. I8I). What remained in terms of experience from World War I was not the beneficial effects of inflation but the need for extending controls beyond the immediate needs of the war time economy (Moggridge and Howson I974, p. 23 I).

The analysis supports the established view in British historiography that financial policy after World War II should be regarded as a continuation of 'cheap money' and a policy of necessity rather than a grand scheme of expropriating bondholders. As such, British financial policy in the I940s and I950s was discontinuous and highly context-dependent, rather than the starting point of a long era of 'financial repression'. It is no coincidence that the periodisation is different and much more 
detailed in the studies of British postwar finance than in studies on 'financial repression'. This difference echoes sceptical comments by Schnabel (20 I 5) and Allen (20I4, 20I9) regarding the validity of 'financial repression' as a distinguishable 'era'. If neither real interest rates nor policy displayed much stability between the I940s and I970s, there is reason to doubt such a periodisation.

\section{IV}

Should Keynes's writings during World War II, in particular his How to Pay for the War, be considered a policy guide for 'financial repression'? A close reading of the sources provides little support for the current status of How to Pay for the War as a sort of founding document for an 'era of financial repression'. What can be confirmed is that How to Pay for the War highlights the necessity of control and state intervention at that time to cope with the financial burdens of the war economy. As such, the pamphlet addresses a particular situation (Trevithick 1975). From a broader perspective of Keynes's oeuvre, his support of state intervention is no outlier; it reflects a general distrust of laissez-faire principles, including the need for low real interest rates and international capital controls whenever necessary for the 'management of the domestic economy', as he later wrote to Roy Harrod (Keynes I942, p. I46). These views became widespread in the I94OS and substantiated the 'embedded liberalism' of the global economy until the end of Bretton Woods (Helleiner I994), including elements of 'financial repression'. How to Pay for the War itself, however, provides few general insights into the terms of long-term policy recommendations. Thus, as a shortcut to understanding the underlying principles of 'financial repression' after World War II, the pamphlet does not qualify.

More important, regarding the problem of 'money illusion' and the use of inflation as a policy tool, How to Pay for the War and the supplementary writings provide no guidance. Keynes neither believed - in line with Leijinhufvud (I98I) - in 'money illusion' nor in inflation. On the contrary, the entire document is a warning against the use of inflation for the financing requirements of the state. On the one hand, inflation is presented as distributively unjust, turning against small savers and putting more money than necessary in the hands of the 'profiteers'. On the other hand, inflation might have proven to be unreliable in a world in which the 'old laws' of laissez-faire seemed no longer to be working. While the first point reflects a lack of alternatives rather than public awareness, the second hints at the evolutionary nature of inflation in a changing social context. Therefore, neither inflation nor inflation awareness could be modelled in a general sense, which could explain why it has proved so difficult to identify Keynes's views on the concept of 'money illusion' (Chytilova 20 I7). This interpretation of Keynes also suggests that there was no 'master plan' by the I940s of expropriating bondholders, which is insinuated by the references made to How to Pay for the War.

While the analysis confirms the attempts by O'Connell (20I6) and earlier writers (Moggridge and Howson I974; Trevithick 1975; Leeson 1996) to 'rescue' Keynes 
from charges of being an 'inflationist', there is also an important and more general point. Economists have treated the transition from 'Keynesianism' to 'Monetarism' as homo oeconomicus's liberation from the irrationality of 'money illusion'. This view had far-reaching implications for economic theorising, for monetary and fiscal policy, and for labour-market regulations. The view also underpinned the transition to 'financial liberalization' (McKinnon I973). This interpretation is legitimate in so far as 'Keynesian' economists such as Duesenberry (I950) did indeed interpret Keynes's writings - the 'General Theory' and How to Pay for the War in particular - as containing the assumption of a stable 'money illusion' (Trevithick 1975). However, putting Keynes himself into perspective reveals that little is gained by trying to bring 'money illusion' back into economic modelling without paying attention to the complexity of changing social settings. This argument echoes Charles Kindleberger's scepticism of interpreting inflation by adhering to technical economic theories at the expense of 'the socio-economic matrix in which the economic events take place' (Kindleberger 1984, p. 3I).

Finally, this analysis provides little support for the idea of an 'era of financial repression', which has become an important label for periodising the postwar world from a financial perspective. The low real interest rates during and immediately after World War II were a direct effect of having learned about the difficult transition of moving from a war economy to a postwar world, and in particular the burden that high public debt levels could place on the state. The high bank rates that had been imposed in the UK following World War I to deal with inflationary pressures had proven disastrous. Keynes's policy prescriptions were, thus, inherently anti-inflationary to avoid such problems. Although, in many other writings, Keynes expressed general sympathy for capital controls, at least regarding the short-term speculative type (Chwieroth 20Io, p. 68), there is little to no evidence that Keynes, the Treasury or the Bank of England had an interest in inflation as a 'mighty tax gatherer'. This lack of evidence does not mean that there is no ground for seeing the period from the end of World War II to the mid I970s as a distinguishable 'era'. Nevertheless, 'financial repression' understood as a combination of state control and inflationary expropriation might not be the most suitable label for doing so.

Submitted: 3 I January 2020

Revised version submitted: I I May 2020

Accepted: Io June 2020

\section{References}

AKERLOF, G. A. and SHILlER, R. (20 I0). Animal Spirits: How Human Psychology Drives the Economy, and Why It Matters for Global Capitalism. Princeton, NJ: Princeton University Press.

ALDRICH, M. (2OI3). Tariffs and trusts, profiteers and middlemen. popular explanations for the high cost of living, I 897-1920. History of Political Economy, 45(4), pp. 693-746. 
ALLEN, W. A. (2012). Government debt management and monetary policy in Britain since I9I9. BIS Paper no. 65, pp. I 5-50.

ALLEN, W. A. (20 I4). Monetary Policy and Financial Repression in Britain, 1951-59. Basingstoke: Palgrave Macmillan.

ALLEN, W. A. (20I9). The Bank of England and the Government Debt: Operations in the Gilt-Edged Market, 1928-1972. Cambridge: Cambridge University Press.

ASPROMOURGOS, T. (20I4). Keynes, Lerner, and the question of public debt. History of Political Economy, 46(3), pp. 409-33.

BALDERSTON, T. (I989). War finance and inflation in Britain and Germany, I9I4-I9I8. Economic History Review, 42(2), pp. 222-44.

BANK OF ENGLAND (I956). The Bank of England I939-45 (Unpublished War History). Accessed via: www.bankofengland.co.uk/archive/bank-of-england-I939-45-ww2

BASSETTO, M. and GALLI, C. (20I9). Is inflation default? The role of information in debt crises. American Economic Review, I09(Io), pp. 3556-84.

BATTILOSSI, S. (2005). The second reversal: the ebb and flow of financial repression in Western Europe, I960-9I. Paper presented at the Sixth Conference of the European Historical Economics Society (EHES), Istanbul, 9-Io September 2005.

BINDER, C. C. (20I6). Estimation of historical inflation expectations. Explorations in Economic History, 6I, pp. I-3I.

BLOMMESTEIN, H. J. and TURNER, P. (2012). Interactions between sovereign debt management and monetary policy under fiscal dominance and financial instability. BIS Papers no. 65, pp. 2 I $3-38$.

BREDIN, D. and FOUNTAS, S. (2018). US inflation and inflation uncertainty over 200 years. Financial History Review, 25(2), pp. I4I-59.

BROADBERRY, S. and HOWLETT, P. (20i6). Lessons learned? British mobilization for the two world wars. In J. Eloranta, E. Golson, A. Markevich and N. Wolf (eds.), Economic History of Welfare and State Formation. Studies in Economic History. Singapore: Springer.

CHWIEROTH, J. M. (20I0). Capital Ideas: The IMF and the Rise of Financial Liberalization. Princeton, NJ: Princeton University Press.

CHYTILOVA, H. (20 I7). Economic Literacy and Money Illusion: An Experimental Perspective. New York: Routledge.

COGLEY, T. and SARGENT, T. J. (2015). Measuring price-level uncertainty and instability in the United States, I 850-2012. Review of Economics and Statistics, 97(4), pp. 827-38.

COLES, A. J. (I978). The moral economy of the crowd: some twentieth-century food riots. Journal of British Studies, I8(I), pp. I 57-76.

CRAFTS, N. (20I6). Reducing high public debt ratios: lessons from UK experience. Fiscal Studies, 37(2), pp. $20 \mathrm{I}-23$.

DANIEL, V. and TER STEEGE, L. (2020). Inflation expectations and the recovery from the Great Depression in Germany. Explorations in Economic History, 75(Jan.), I I 305.

DAUNTON, M. J. (I996). How to pay for the war: state, society and taxation in Britain, I9I7-24. English Historical Review, III(Sept.), pp. 882-9I9.

DAUNTON, M. J. (2002). Just Taxes: The Politics of Taxation in Britain, 1914-1979. Cambridge: Cambridge University Press.

DORNBUSCH, R. and DRAGHI, M. (I990). Introduction. In M. Draghi and R. Dornbusch (eds.), Public Debt Management: Theory and History. Cambridge: Cambridge University Press.

DUESENBERRY, J. (I950). The mechanism of inflation. Review of Economics and Statistics, 32(2), pp. I 44-9.

END, N., MARINKOV, M. and MIRYUGIN, F. (20I9). Instruments of debtstruction: public debt management and networks during the interwar period. AMSE Working Papers no. I933.

FFORDE, J. (I992). The Bank of England and Public Policy, 1941-1958. Cambridge: Cambridge University Press.

FOREMAN-PECK, J. S. (2002). The debt constraint on British economic policy and performance in the I920s. In M. J. Oliver (ed.), Studies in Economic and Social History: Essays in Honour of Derek H. Aldcroft. Aldershot: Ashgate.

FRY, M. J. (1989). Financial development: theories and recent experience. Oxford Review of Economic Policy, 5(4), pp. I $3-28$. 
GOODHART, C. A. E. (20Io). The changing role of central banks. BIS Paper no. 326, pp. I-I6.

HELLEINER, E. (1994). States and the Reemergence of Global Finance: From Bretton Woods to the 1990s. Ithaca, NY: Cornell University Press.

HICKS, J. (1939). Hicks to Keynes, 4 Oct. I939. In J. M. Keynes (20I3), The Collected Writings of John Maynard Keynes, vol. 22. Cambridge: Cambridge University Press.

HICKS, J. (I990). The unification of macro-economics. The Economic Journal, Ioo(40I), pp. 528-38.

HOWSON, S. (1975). Domestic Monetary Management in Britain, 1919-38. Cambridge: Cambridge University Press.

HOWSON, S. (1993). British Monetary Policy, 1945-51. Oxford: Clarendon Press.

HUNT, K. (20IO). The politics of food and women's neighborhood activism in First World War Britain. International Labor and Working-Class History, 77(I), pp. 8-26.

KEYNES, J. M. (I9I9). Inflation (from The Economic Consequences of the Peace, chapter 6, 'Europe after the Treaty'). In J. M. Keynes (2OI3), The Collected Writings of John Maynard Keynes, vol. 9. Cambridge: Cambridge University Press.

KEYNES, J. M. (I922). Lecture to the Institute of Bankers, 29 November I922. In J. M. Keynes (20I3), The Collected Writings of John Maynard Keynes, vol. I9. Cambridge: Cambridge University Press.

KEYNES, J. M. (I923). A tract on monetary reform. In J. M. Keynes (2013), The Collected Writings of John Maynard Keynes, vol. 4. Cambridge: Cambridge University Press.

KEYNES, J. M. (I939a). Paying for the war (from The Times, I4 and is Nov. I939). In J. M. Keynes (2013), The Collected Writings of John Maynard Keynes, vol. 22. Cambridge: Cambridge University Press.

KEYNES, J. M. (I939b). Price policy (Memorandum), I4 Sept. In J. M. Keynes (2013), The Collected Writings of John Maynard Keynes, vol. 22. Cambridge: Cambridge University Press.

KEYNES, J. M. (1939c). To the Editor of The Times, 28 Sept. In J. M. Keynes (2013), The Collected Writings of John Maynard Keynes, vol. 22. Cambridge: Cambridge University Press.

KEYNES, J. M. (I939d). To the Editor of The Times, 29 Nov. In J. M. Keynes (2013), The Collected Writings of John Maynard Keynes, vol 22. Cambridge: Cambridge University Press.

KEYNES, J. M. (I939e). Mr Keynes and his critics: a reply and some questions (from The Times, 28 Nov. 1939). In J. M. Keynes (2013), The Collected Writings of John Maynard Keynes, vol. 22. Cambridge: Cambridge University Press.

KEYNES, J. M. (1940a). How to Pay for the War: A Radical Plan for the Chancellor of the Exchequer. New York: Harcourt, Brace and Company.

KEYNES, J. M. (I940b). Keynes to H. J. Laski, 28 January I940. In J. M. Keynes (2013), The Collected Writings of John Maynard Keynes, vol. 22. Cambridge: Cambridge University Press.

KEYNES, J. M. (I940c). Keynes to the Editor of the New Statesman, 6 April I940. In J. M. Keynes (20I3), The Collected Writings of John Maynard Keynes, vol. 22. Cambridge: Cambridge University Press.

KEYNES, J. M. (I940d). Keynes to G. Dawson, I I March I940. In J. M. Keynes (2013), The Collected Writings of John Maynard Keynes, vol. 22. Cambridge: Cambridge University Press.

KEYNES, J. M. (I940e). Keynes to M. Norman, 3 March I940. In J. M. Keynes (2013), The Collected Writings of John Maynard Keynes, vol. 22. Cambridge: Cambridge University Press.

KEYNES, J. M. (1942). Keynes to R. Harrod, I9 April I942. In J. M. Keynes (2013), The Collected Writings of John Maynard Keynes, vol. 25. Cambridge: Cambridge University Press.

KINDLEBERGER, C. P. (I984). A structural view of the German inflation. In G. D. Feldman, C. Holtfrerich, G. A. Ritter and P. Witt (eds.), Die Erfahrung der Inflation im internationalen Zusammenhang und Vergleich. Berlin: De Gruyter.

KING, J. E. (1998). Oxford versus Cambridge on how to pay for the war: a comment on Littleboy. History of Economics Review, 27(I), pp. 37-49.

KURABAYASHI, Y. (1994). Keynes's How to Pay for the War and its influence on postwar national accounting. In Z. Kenessey (ed.), The Accounts of Nations. Amsterdam: IOS Press.

LAIDLER, D. E. W. (I99I). The Golden Age of the Quantity Theory. Princeton, NJ: Princeton University Press.

LEESON, R. (I996). Keynesian misjudgments about strikes and inflation. History of Economics Review, 25(I), pp. 67-7I.

LEIJONHUFVUD, A. (198I). Keynes and the Classics: first lecture. In A. Leijonhufvud (ed.), Information and Coordination: Essays in Macroeconomic Theory. Oxford: Oxford University Press. 
LITTLEBOY, B. (1996). The wider significance of How to Pay for the War. History of Economics Review, 25(I), pp. 88-95.

MAIER, C. S. (I984). Inflation and stabilization in the wake of the two world wars: comparative strategies and sacrifices. In G. D. Feldman, C. Holtfrerich, G. A. Ritter and P. Witt (eds.), Die Erfahrung der Inflation im internationalen Zusammenhang und Vergleich. Berlin: De Gruyter.

MAITAL, S. (1972). Inflation, taxation and equity: How to Pay for the War revisited. Economic Journal, 82, pp. I $58-69$.

MALMENDIER, U. and NAGEL, S. (2016). Learning from inflation experiences. Quarterly Journal of Economics, I3I(I), pp. 53-87.

MARINKOV, M. (2OI9). Conquering the debt mountain: financial repression and Italian debt in the interwar period. In E. Dabla-Norris (ed.), Debt and Entanglements between the Wars. Washington, DC: International Monetary Fund.

MCKIBBIN, R. (2010). Parties and People: England, 1914-1951. Oxford: Oxford University Press.

MCKIBBIN, R. (20I3). Political sociology in the guise of economics: J. M. Keynes and the rentier. English Historical Review, I28(530), pp. 78-106.

MCKINNON, R. I. (I973). Money and Capital in Economic Development. Washington, DC: Brookings Institution.

MIDDLETON, R. (2010). British monetary and fiscal policy in the I930s. Oxford Review of Economic Policy, 26(3), pp. 4I 4-4I.

MILL, J. S. (I87I). The Principles of Political Economy with Some of Their Applications to Social Philosophy, 7 th edn. London.

MOGGRIDGE, D. E. (1972). British Monetary Policy, 1924-1931: The Norman Conquest of \$4.86. Cambridge: Cambridge University Press.

MOGGRIDGE, D. E. (I992). Maynard Keynes: An Economist's Biography. London: Routledge.

MOGGRIDGE, D. E. (2002). Rescuing Keynes from the economists? The Skidelsky trilogy. European Journal of the History of Economic Thought, 9(I), pp. I I I-23.

MOGGRIDGE, D. E. and HOWSON, S. (I974). Keynes on monetary policy, I9IO-I946. Oxford Economic Papers, 26(2), pp. 226-47.

MONNET, E., PAGLIARI, S. and VALLÉE, S. (20I4). Europe between financial repression and regulatory capture. Bruegel Working Paper no. 20I4/08.

NASON, J. M. and VAHEY, S. P. (2007). The McKenna rule and UK World War I finance. American Economic Review, 97(2), pp. 290-4.

NORMAN, M. (I940). Norman to Keynes, 28 February I940. In J. M. Keynes (20I3), The Collected Writings of John Maynard Keynes, vol. 22. Cambridge: Cambridge University Press.

O'CONNELL, J. (20I6). On Keynes on inflation and unemployment. European Journal of the History of Economic Thought, 23(I), pp. 82-IOI.

REINHART, C. M. (2OI2). The return of financial repression. Financial Stability Review, I6(April), pp. 37-48.

REINHART, C. M. and SBRANCIA, M. B. (20I5). The liquidation of government debt. Economic Policy, 30(82), pp. 29I-325.

ROUBINI, N. and SALA-I-MARTIN, X. (I995). A growth model of inflation, tax evasion, and financial repression. Journal of Monetary Economics, 35(2), pp. 275-30I.

SANUSI, K. A. and AKINLO, A. E. (20I6). Investigating fiscal dominance in Nigeria. Journal of Sustainable Development, 9(I), pp. I25-3 I.

SANZ BAS, D. (20I9). 'How to pay for the war': gasto público e inflación. Anuario Jurídico y Económico Escurialense, 52, pp. 277-306.

SARGENT, T. (20I3). The ends of four big inflations. In T. Sargent (ed.), Rational Expectations and Inflation, 3rd edn. Princeton, NJ: Princeton University Press.

SARGENT, T. J. and WALLACE, N. (I98I). Some unpleasant monetarist arithmetic. Federal Reserve Bank of Minneapolis Quarterly Review, 5(3), pp. I-I7.

SAYERS, R. S. (I956). Financial Policy 1939-45. London: HM Stationery Office

SCHNABEL, I. (20I5). Discussion: Reinhart, C. M. and Sbrancia, M. B., 'The liquidation of government debt'. Economic Policy, 30(82), pp. 325-8.

SHAW, E. S. (1973). Financial Deepening in Economic Development. New York: Oxford University Press. 
TILY, G. (2006). Keynes's theory of liquidity preference and his debt management and monetary policies. Cambridge Journal of Economics, 30(5), pp. 657-70.

TILY, G. (2009). John Maynard Keynes and the development of national accounts in Britain, I 895-I94I. Review of Income and Wealth, 55(2), pp. 33 I-59.

TOYE, R. (1999). Keynes, the Labour Movement, and 'How to Pay for the War'. Twentieth Century British History, Io(3), pp. 255-8I.

TREVITHICK, J. A. (I975). Keynes, inflation and money illusion. Economic Journal, 85(337), pp. IOI-I3.

TURNER, P. (20II). Fiscal dominance and the long-term interest rate. Financial Markets Group Special Paper Series, Special Paper 199.

VAN RIET, A. G. (20I8). Financial Repression and High Public Debt in Europe. Tilburg: CentER, Center for Economic Research.

WALLICH, H. C. (1946). Debt management as an instrument of economic policy. American Economic Review, 36(3), pp. 292-3 Iо.

WEIR, M. (I989). Ideas and politics: the acceptance of Keynesianism in Britain and the United States. In P. A. Hall (ed.), The Political Power of Economic Ideas: Keynesianism across Nations. Princeton, NJ: Princeton University Press.

WHITE, M. V. and SCHULER, K. (2009). Retrospectives: who said 'debauch the currency': Keynes or Lenin? Journal of Economic Perspectives, 23(2), pp. 21 3-22.

WOOTTON, B. (I940). Who shall pay for the war? Political Quarterly, II, pp. I43-54.

WORMELL, J. (2002). The Management of the National Debt of the United Kingdom 1900-1932. London and New York: Routledge. 